\title{
Structure, Genetics and Worldwide Spread of New Delhi Metallo- $\beta$-lactamase (NDM): a threat to public health
}

\author{
Asad U. Khan ${ }^{1 *}$, Lubna Maryam ${ }^{1}$ and Raffaele Zarrilli ${ }^{2,3^{*}}$ (D)
}

\begin{abstract}
Background: The emergence of carbapenemase producing bacteria, especially New Delhi metallo- $\beta$-lactamase (NDM-1) and its variants, worldwide, has raised amajor public health concern. NDM-1 hydrolyzes a wide range of $\beta$-lactam antibiotics, including carbapenems, which are the last resort of antibiotics for the treatment of infections caused by resistant strain of bacteria.

Main body: In this review, we have discussed bla $a_{N D M-1}$ variants, its genetic analysis including type of specific mutation, origin of country and spread among several type of bacterial species. Wide members of enterobacteriaceae, most commonly Escherichia coli, Klebsiella pneumoniae, Enterobacter cloacae, and gram-negative non-fermenters Pseudomonas spp. and Acinetobacter baumannii were found to carry these markers. Moreover, at least seventeen variants of bla $a_{\mathrm{NDM}}$-type gene differing into one or two residues of amino acids at distinct positions have been reported so far among different species of bacteria from different countries. The genetic and structural studies of these variants are important to understand the mechanism of antibiotic hydrolysis as well as to design new molecules with inhibitory activity against antibiotics.
\end{abstract}

Conclusion: This review provides a comprehensive view of structural differences among NDM-1 variants, which are a driving force behind their spread across the globe.

Keywords: Enterobacteriaceae, New Delhi-Metallo-Beta-Lactamases, Carbapenemases, Antibiotic resistance

\section{Background}

Although antibiotics were developed to fight infections, the emergence of new resistant markers, especially New Delhi-metallo-beta-lactamases (NDM-1), hampered the capability of all antibiotics of beta lactam group to treat infections caused by microorganisms carrying such resistances. The possible reason for evolving trends of new markers is mutations [1], which may cause delaying in the discovery of new antibiotics for treatments and hence became a great public threat [2]. The overuse of antibiotics is one of the reasons to cause resistance, due to increase selective pressure in a specific population of

\footnotetext{
*Correspondence: asad.k@rediffmail.com; rafzarri@unina.it

${ }^{1}$ Medical Microbiology and Molecular Biology Laboratory, Interdisciplinary

Biotechnology Unit, Aligarh Muslim University, Aligarh 202002, India

${ }^{2}$ Department of Public Health, University of Napoli Federico II, Italy, Naples,

Italy

Full list of author information is available at the end of the article
}

bacteria allowing the resistant bacteria to bloom and the susceptible bacteria to pass away.

Enzymes are evolving over a period of time by mutations in response to environmental pressure for increased stability and fitness leading to its functional changes. The activity of an enzyme and its future generations success in response to change conditions due to environmental stress and its improved physiological utility for constant perseverance is determined by these evolutionary drivers. Recent reports on antibiotic resistance has made a clear understanding of evolving status of $\beta$-lactamase enzymes, which are key player for antibiotic resistance [3].

In Enterobacteriaceae and other Gram-negative bacteria including Pseudomonas and Acinetobacter species, production of carbapenemases has become a noteworthy mechanism for broad-spectrum $\beta$-lactam resistance [4]. Carbapenemases may be defined as specific beta-lactamases, which hydrolyze carbapenem group of 
antibiotics. These are involved in acquired resistance and belong to Ambler molecular classes A, B and D [4].

Intestinal carriage of carbapenemase-producing organisms (CPOs) is an important source of its transmission [5]. However, detection of carbapenemase producing Gramnegative bacteria has become a major concern for the hospital settings to control infections. Use of multiplex PCR analyses and DNA microarray have been reported as rapid detection systems. Most prevalent carbapenemases detected by these systems are KPC and OXA serine carbapenemases [6].

A number of new variants of class A carbapenemases (e.g., KPC and GES enzymes), class B metallo-betalactamases (e.g., IMP, VIM and NDM metallo-betalactamases), and class D carbapenemases (e.g., OXA-23) are emerging over time scale. Moreover, over-expression of class C beta-lactamases, such as CMY-10 and PDC type beta-lactamases, which are weak carbapenemases, can also lead to carbapenem resistance, especially in combination with other resistance mechanisms [7].

Metallo-beta-Lactamases (MBLs) are class B $\beta$-lactamases that hydrolyze almost all clinically-available $\beta$-lactam antibiotics and feature the distinctive $\alpha \beta / \beta \alpha$ sandwich fold of the metallo-hydrolase/oxidoreductase superfamily.
MBLs possess a shallow active-site groove with one or two divalent zinc ions, bordered by flexible loops [8]. In NDM-1 this flexible hairpin loop moves over the zinc ion for hydrolysis and is later removed after the catalysis [9]. The 3D structure of NDM-1 with active site and Zinc molecules is shown in Fig. 1. MBLs are classified into three subclasses (B1, B2 and B3), according to sequence identity and zinc ion dependence, of which the B1 subclass included most clinically significant enzymes. Not many inhibitors have been successfully designed due to the nature of zinc ligands, catalytic mechanisms and the differences among the active site architecture [8]. The evolution of varied and detrimental range of $\beta$-lactamases has lost the effectiveness of $\beta$-Lactamase inhibitors (BLIs) which could play an important role in combating $\beta$-lactam resistance in Gram-negative bacteria [10]. A triple combination of meropenem/piperacillin/tazobactam $\beta$-lactams, has been proved as one of the strategies to kill Methicillin-resistant Staphylococcus aureus (MRSA) in vitro as well as in a mouse model through a novel synergistic mechanism of action [10].

A bacterium carrying several antibiotic-resistant genes is called multi-resistant bacteria or informally, a "super bacteria" or "super bug"; infections caused by them are

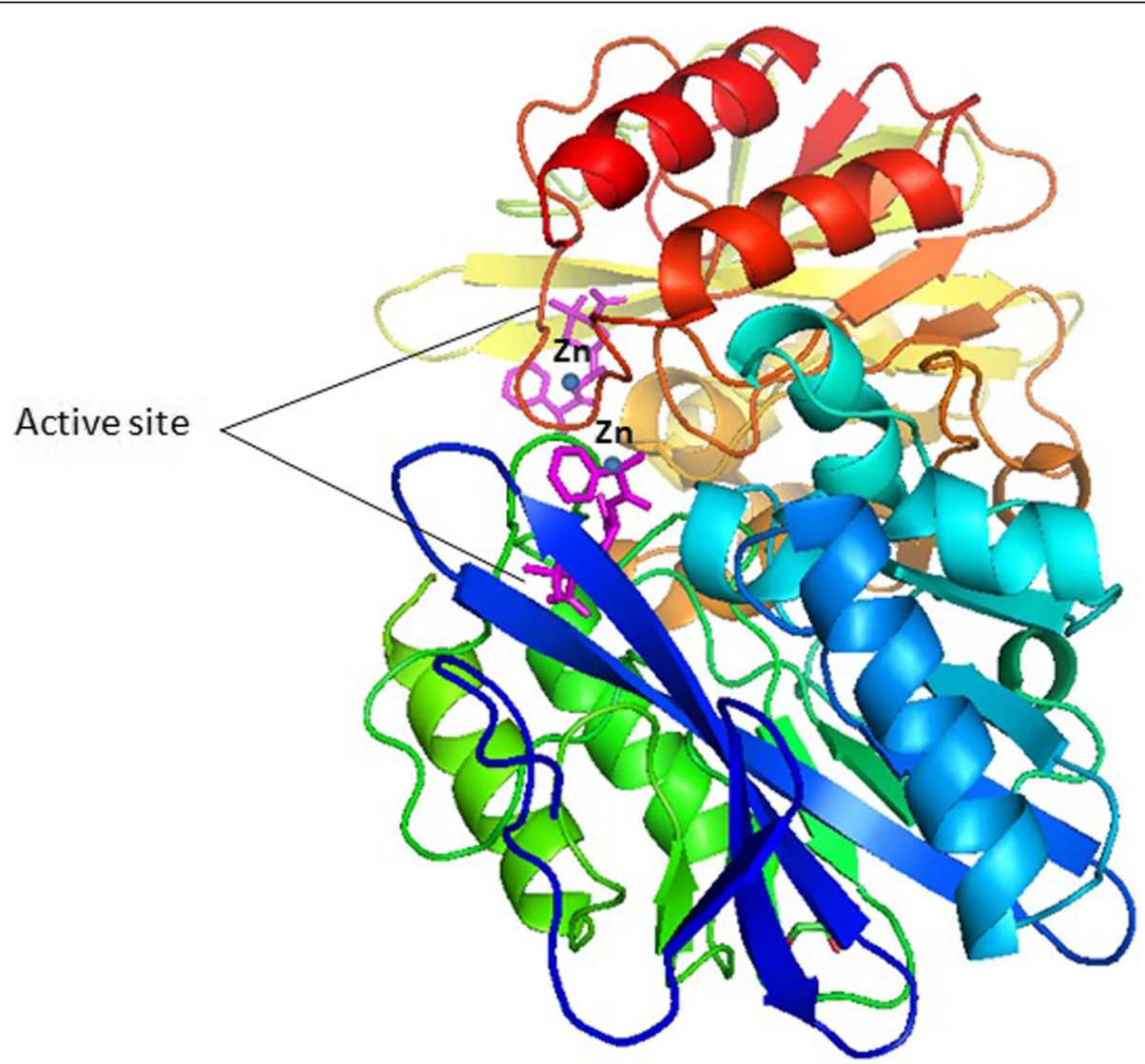

Fig. $13 \mathrm{D}$ structure of NDM-1 protein backbone shown with helices and strands, the two zinc ions at the active sites are shown as blue spheres 
difficult to treat [11]. Most probably, a very rare "genetic fusion" is thought to occur between two previously known antibiotic-resistant genes that evolved to a new mutant called NDM-1.The product of the $b l a_{\mathrm{NDM}-1}$ gene is NDM, an enzyme hydrolysing broad range of antibiotics, including the carbapenems, which are considered as last resort of antibiotics. In the last few years, 17 new variants of NDM-1 have been evolved by changing one or two residues at different positions [12-15]. The emergence of bacteria carrying such genes represent a big challenge for physicians to treat infected patients.

\section{Mechanism of resistance}

The expression of $\beta$-lactamases, efflux pumps and alteration of porins and penicillin binding proteins (PBPs) are the common mechanism for carbapenem resistance in member of Enterobacteriaceae. Combinations of these mechanisms can cause high levels of resistance to carbapenems in certain bacterial species, such as K. pneumoniae, Pseudomonas aeruginosa and $A$. baumannii. In $P$. aeruginosa carbapenem resistance is contributed also by the loss of OprD porin leading to decrease in outer membrane permeability, increase in cytoplasmic membrane active efflux pump system, up regulation and alteration in carbapenem hydrolyzing enzymes and penicillin binding proteins [16]. Acquisition of metallo-beta lactamases (MBL), which hydrolyze the carbapenems and all beta lactams except the monobactams, is one of the emerging mechanism of carbapenem resistance [17]. Multi-drugresistant Pseudomonas aeruginosa (MDRPA) infection risk factors include immunocompromised states, prolonged hospitalization and antimicrobial therapy [18]. NDM-1 producing $P$. aeruginosa isolates were detected for the first time in Serbia [19]. In all four $P$. aeruginosa isolates detected, $b l a_{\mathrm{NDM}-1}$ genes were present on $50 \mathrm{~kb}$ plasmid (Gene Bank accession numbers JX680682, JX680683, JX680684 and JX680685) [20].The co-expression of $b l a_{\mathrm{NDM}-1}$ and MexAB-OprM efflux pump occurred into a $P$. aeruginosa strain upon single dose of meropenem therapy, thus suggesting that both mechanisms contribute to carbapenem resistance, although the efflux system played the major role [21]. One more example of combinatorial effects in $A$. baumannii harbouring $b l a_{\mathrm{NDM}}$ is the expression of multiple efflux systems and altered membrane permeability [22].

A distinction exists between resistance to carbapenems in Gram-positive cocci and Gram-negative rods. In Gram-positive cocci, carbapenem resistance is typically the result of substitutions in amino acid sequences of PBPs or acquisition/production of a new carbapenemresistant PBP. Expression of beta-lactamases and efflux pumps, as well as porin loss and alterations in PBP, are all associated with carbapenem resistance in Gramnegative rods [23]. For example, a clinical strain HPC299
Acinetobacter bereziniae, harbouring $b l a_{\mathrm{NDM}-1}$, uses multidrug efflux pumps as its adaptation strategy for survival under different environmental conditions [24]. Carbapenem resistance mechanisms not related to carbapenemase production include increase in efflux pump activity [25] and modifications of outer membrane porin profiles, which regulate access of carbapenems to the cell wall [26].

\section{Multi-drug resistance by ndm-1 producing bacteria Background of NDM-1 producers}

There are hundreds of commensal strains of $E$. coli bacteria, which are not associated with any infectious diseases. However, emergence of a new mutant strain known as NDM-1 producing $E$. coli has thrown light on the fact that the development of antibiotic resistance among microorganisms can transform commensals into pathogens. Many NDM-1 variants evolved in Enterobacteriaceae, Vibrionaceae and other non-fermenters by single and double amino acid residue substitutions at different positions [27], for e.g., NDM-1 (major variant), NDM-2, NDM-3, NDM-4and NDM-5 (minor variants), reported worldwide [12, 28, 29]. New Delhi metallo-beta lactamase (NDM) produced by bacterial isolates from the Indian subcontinent are the latest carbapenemases, which hydrolyze all beta lactam antibiotics (except aztreonam), including the broad spectrum antibiotic "carbapenems", thereby causing havoc in hospitals and community [30]. The gene encoding NDM-1 is often carried by plasmids and hence easily moves to other microorganisms via horizontal gene transfer, thereby increasing the probability of emergence of drug resistant strains of pathogenic microorganisms [31].

\section{Major healthcare risk of NDM producers}

NDM-1 strains are particularly hazardous because: (i) most plasmids detected in these bacteria are transferable and capable of wide rearrangement, suggesting a widespread horizontal transmission and flexibility among bacterial populations; (ii) there is lack of a routine standardized phenotypic test for metallo-beta-lactamase (MBL) detection; (iii) there is consequent probable high prevalence of unrecognized asymptomatic carriers; (iv) there is a lack of available effective antibiotics for the treatment of multidrug resistant NDM-1 expressing bacteria [31].

NDM-1 producing E. coli infects the host by commonly invading sites like, urinary tract, blood, lungs, and wounds, leading to urinary tract infections, septicaemia, pulmonary infections, diarrhoea, peritonitis, device-associated infections and soft tissue infections [12]. These antibiotic resistant bacteria express type IV secretion system as their virulence factor, which allows them to introduce bacterial proteins and enzymes inside the host cell, thereby controlling the host cell metabolism [32]. Mode of transmission of NDM-1 producing strain could either 
be through cross-contamination during food preparation or via body fluids and may occur in the community or in the hospital setting [33].

\section{Worldwide distribution of NDM variants across the globe}

Asian continent serves as the major reservoir of NDM producers, with around $58.15 \%$ abundance of NDM-1 variant distributed mostly in China and India. Additional file 1: Table S1 shows detailed prevalence of NDM-1 and its variants in different countries worldwide. Europe shows around $16.8 \%$ of the total producers, with the maximum spread of NDM-1 variant in Bulgaria, Romania, Poland, France, Italy, Turkey, Germany, Greece, Serbia, London, Ukraine, Croatia, Azerbaijan and Ireland. NDM-4 is also reported to be distributed in European subcontinent in Italy, while NDM-5 and NDM-7 are prevalent in Denmark and France (Additional file 1: Table S1). American continent shows around $10.8 \%$ abundance of the total NDM-1 producers as reported globally, of which subcontinent Brazil serves as the major reservoir while Colorado, Mexico city, California, Georgia, Illinois, Paraguay, Pennsylvania, Florida, Argentina, Jamaica, Uruguay and Ecuador are considered as minor pool (Additional file 1: Table S1). Africa carries around $10.8 \%$ pool of the total NDM-1 producers scattered globally. African subcontinent, Algeria showed major distribution, whereas Greater Johannesburg Area, KwaZulu-Natal, Libya, Madagascar, Egypt and Tunisia demonstrated low prevalence of these NDM-1 producers. NDM-5 is also reported to be distributed in Algeria (Additional file 1: Table S1). Australia serves as the $1.6 \%$ reservoir of the total NDM-1 producers distributed in Brisbane, Perth and New Zealand. Highest distribution of these NDM variants is detected in K. pneumoniae and E. coli species (Additional file 1: Table S1).

NDM-1 producers were found resistant to imipenem, meropenem, ertapenem, gentamicin, amikacin, tobramycin, and ciprofloxacin, whereas, isolates were found susceptible to colistin (MICs $\leq 4 \mathrm{mg} / \mathrm{L}$ ) and to tigecycline (MICs $\leq 1 \mathrm{mg} / \mathrm{L}$ ) [34]. Non-clonal Indian isolates from Chennai had bla $a_{\mathrm{NDM}-1}$ exclusively on plasmids of size ranging from 50 to $350 \mathrm{~kb}$, whereas another clone of $K$. pneumoniae isolated in Haryana was found to have plasmid of predominately either $118 \mathrm{~kb}$ or $50 \mathrm{~kb}$, suggesting wide environmental spread of $b l a_{\mathrm{NDM}-1}$ [34]. Plasmid profiling showed that a plasmid of size $50 \mathrm{~kb}$ carries bla $_{\mathrm{NDM}-1}$ in Enterobacteriaceae, which were found resistant to almost all antimicrobials except tigecycline and colistin [34].

In Europe, dissemination of NDM-1 has been observed in A. baumannii isolates assigned to international clonal lineage I and to the emerging genotypes ST25 and ST85 $[35,36]$. The $b l a_{\mathrm{NDM}-1}$ gene was inserted within a Tn125like transposon which was either chromosomally-located [35] or plasmid-located [35, 36] (Fig. 2).
NDM-producing resistant $E$. coli strains were also found in animal sources [37]. Acinetobacter lwoffii carrying $b l a_{\mathrm{NDM}-1}$ gene on plasmid were isolated from chicken rectal swab [38]. The bla NDM gene detection in dairy cattle is a matter of concern because it may lead to spread through food chain. Sequence analysis revealed a gene showing 100\% homology with E. coli (JQ348841.1) bla $a_{\mathrm{NDM}-5}$ gene and 99\% homology with $E$. coli (JQ348841.1) bla NDM-4 $_{\text {in }}$ Pseudomonas aeruginosa (HF546976.1), K. pneumoniae (KC178689.1), Raoultella ornithinolytica (JX680686.1), A. baumannii (KC404829.1, KC347597.1). Apart from this, NDM-1 producing Enterobacter cloacae (EC15) and $K$. pneumoniae (KP12) strains were isolated from two patients with diabetic foot ulcers in 2010 from northern part of India [39].

The origin of NDM-1 started in the year 2008 when the first case of a NDM-1 episode was reported in a Swedish patient previously hospitalized in New Delhi, suffering from a multidrug-resistant $K$. pneumoniae, urinary tract infection [40]. Based on the number of victims affected with NDM-1 strains in various parts of the globe, it has been estimated that the Indian subcontinent is the main reservoir of NDM-1 producers [39], next down the line is United Kingdom. On the other hand, Belgium, China, Japan, France, Austria, Germany, Norway, Hong Kong, Sweden, Netherland, Australia and Canada also serve as the secondary reservoirs of bla $a_{\mathrm{NDM}}$ genes [39] as shown in Additional file 1: Table S1. An average of 1000-1600 patients are admitted daily to the hospitals worldwide as a result of infections due to drug resistant bacteria [41]. It is difficult to predict the rate of spread of the gene encoding NDM- 1, although exchange of the bla $a_{\mathrm{NDM}-1}$ gene among unrelated bacterial isolates have been identified already in Enterobacteriaceae and A. baumannii [34]. An increase in population exchange at global level and enhanced medical tourism could play a significant role in spreading uncontrolled NDM-1 related resistance worldwide.

\section{Genetic and Biochemical analysis of NDM variants}

The $b l a_{\mathrm{NDM}-1}$ gene which encodes for the New Delhi metallo- $\beta$-lactamase 1 (NDM- 1 ) is commonly found among members of Enterobacteriaceae and Pseudomonas species $[34,42]$. The above bacteria are highly resistant to all antibiotics including carbapenems and aminoglycosides because of co-existence of $r m t F$ methylase gene in most of the isolates [43], but susceptible to tigecycline and colistin [34]. However, $b l a_{\mathrm{NDM}-9}$ producing colistin resistant $E$. coli strain was recently discovered in a chicken meat sample in Guangzhou, China [44]. 16S rRNA methyl transferases responsible for high resistance to antibiotics were reported in bla $a_{\mathrm{NDM}-1}$ positive Pseudomonas aeruginosa isolates in co-association with $\mathrm{rmtC}$ and $\mathrm{rmtF}$ genes on the chromosome [45]. IncR plasmid carrying bla $a_{\mathrm{NDM}-1}$ was also reported in Citrobacter koseri acting as a reservoir 


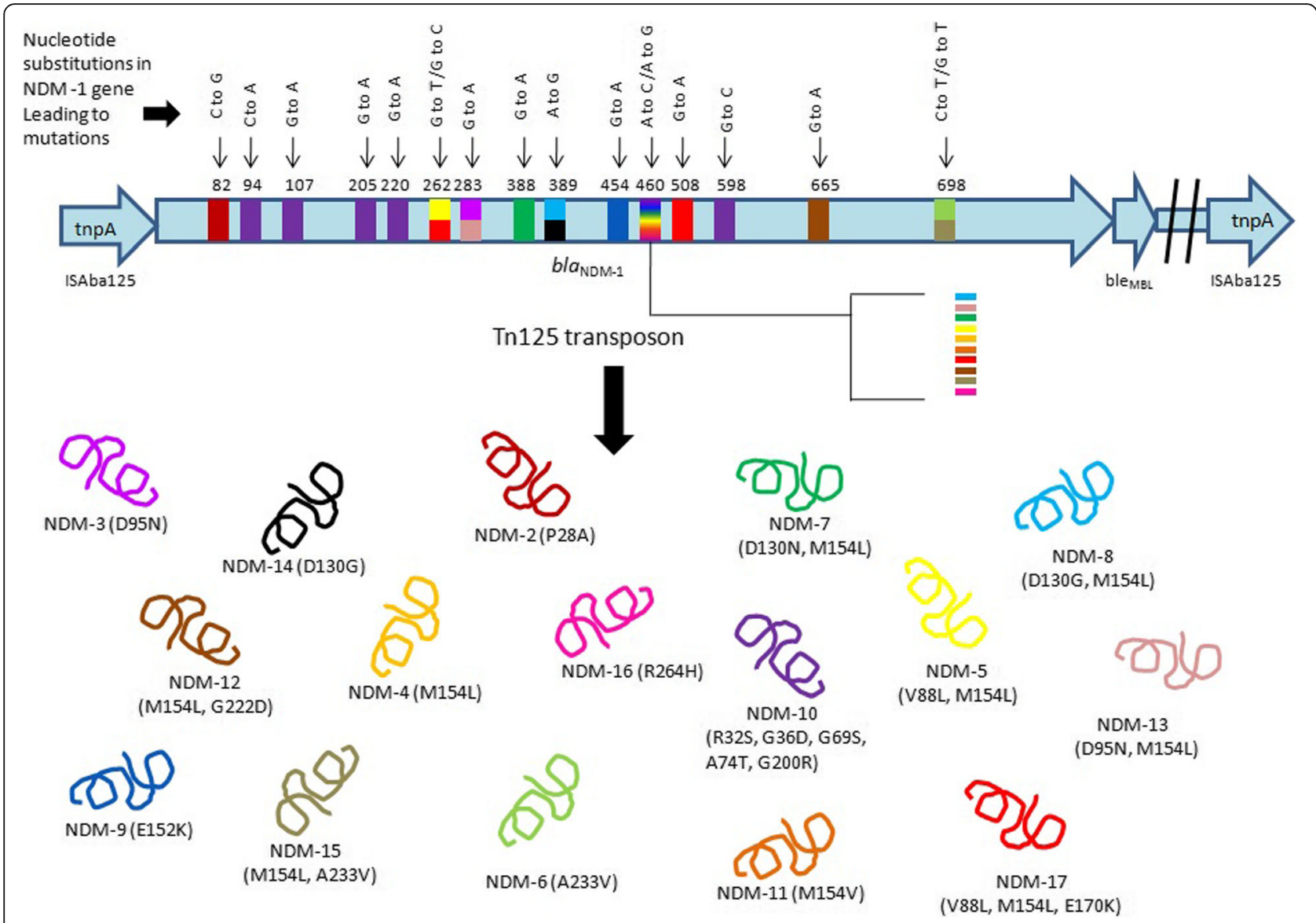

Fig. 2 A schematic representation of bla NDM-1 $_{1}$ gene carrying $T n 125$ transposon, showing the mutations at various nucleotide positions leading to the occurrence of NDM variants. Each unique colour of NDM variant in lower panel showing mutant residues at different position and the same is reflected in gene with the same colour at different position and nucleotide (s)

for multidrug resistance [46]. bla NDM-1 was associated with different plasmid scaffolds (IncFII, IncL/M, IncN, IncR, IncHIB-M/FIB-M), IncF type being the prevalent one. Genetic structures surrounding bla NDM-1 showed its association with at least a remnant of ISAba125 at its $5^{\prime}$ end [47]. Tn125 composite transposon in A. baumannii has been demonstrated to be responsible for $b l a_{\mathrm{NDM}-1}$ gene dissemination within Acinetobacter species and Enterobacteriaceae [48]. ble $e_{\mathrm{MBL}}$ gene, which confers resistance to anti-tumor glycopeptide molecule bleomycin, is found downstream of bla $a_{\mathrm{NDM}-1}$ gene [49] (Fig. 2). There has been an exponential increase in resistance among Gramnegative bacteria compared with Gram-positive bacteria $[50,51]$, while not many new active antibiotics are developed against Gram-negative bacteria [52-54]. Increase in its resistance is mainly due to the presence of mobile elements into conjugative plasmids, which can readily spread through bacterial populations.

The isolates obtained from UK had a more diverse range of plasmid sizes ranging from $80 \mathrm{~kb}$ to greater than $500 \mathrm{~kb}$ [34]. For example, a RB151 strain was reported to harbour $108 \mathrm{~kb}$ plasmid carrying NDM-1 gene on 4.8 Mbp chromosome [55]. E. coli Y5 isolate was found to have $b l a_{\mathrm{NDM}-1}$ on chromosome as well [56].The $b l a_{\mathrm{NDM}-1}$ was also carried by more than one plasmid in some isolates. Most of the plasmids carrying $b l a_{\mathrm{NDM}-1}$ shows transmissibility and plasticity enabling them to diversify and spread among bacterial populations with an alarming potential; many of them were of incompatibility A/C types [34], which is not commonly associated group among multidrugresistant phenotypes. The emergence of new variants of NDM-1 are taking place in India due to widespread use of antibiotics leading to huge selection pressure. Only few antibiotics against Gram-negative bacteria are available and none of them is active against producers of NDM-1 [57]. Large conjugative plasmids are seen to harbour $\mathrm{bla}_{\mathrm{NDM}-1}$ gene along with determinants of antibiotic resistance [58].

In the United States, K. pneumoniae is the most common CRE (carbapenem-resistant Enterobacteriaceae) species, resistant to nearly all available antibiotics encountered, typically as a hospital-acquired infection with high mortality and morbidity rate $[59,60]$. ATCC BAA-2146 (Kpn2146) a 
strain of $K$. pneumoniae was the first reported U.S isolate encoding NDM-1 along with additional antibiotic resistance determinants on plasmid of size $140.8 \mathrm{~kb}$.

At least one zinc atom is present on the active site of all metallo-carbapenemases, which facilitates bicyclic $\beta$-lactam ring hydrolysis [61]. Metallo-carbapenemases have the ability to hydrolyze commercially available carbapenem resistant $\beta$-lactamase inhibitors but show sensitivity to metal ion chelators. Along with carbapenems they can also hydrolyze penicillins and cephalosporins, while the ability to hydrolyze aztreonam is lacking. Hydrolysis occurs when zinc ions on active site interacts with $\beta$ lactams giving distinctive inhibition trait by EDTA.

It has been reported that the $b l a_{\mathrm{NDM}}$ is carried by various types of plasmids such as IncA/C, IncF, IncNIncL/M or untypable/IncR, and is rarely found to be chromosomally integrated [62]. Plasmid characterization demonstrated that different mechanism leads to acquisition of NDM gene even if it is located on very closely related plasmids [63]. The sequencing of few plasmids reveals $b l a_{\mathrm{NDM}}$ association with insertion sequences and transposons, which regulate its horizontal gene transfer and $a a d B, d f r A 12, b_{\text {OXA-30 }}$ and aacA4 additional resistance markers [64]. Tn3000 transposon has been reported to be responsible for $b l a_{\mathrm{NDM}-1}$ dissemination among enterobactericeae [65]. A non-active site residue $\operatorname{Trp} 93$ is found to play role in maintaining the structural integrity of NDM-1, although not being directly involved in recognition and catalysis [66]. Recently, a new plasmid type IncX3 is reported to be responsible for making the spread of NDM gene more effective [67], for example in China IncX3 and InA/C plasmids were reported to be responsible for spread of $b l a_{\mathrm{NDM}}$ genes [68].

Recent studies demonstrated the coexistence of NDM-1 gene along with other resistant genes, such as IMP-1 in Acinetobacter species [69], co-expression of NDM-1 and OXA-232 in an E. coli isolate was reported from Germany [70], co-production of NDM-5 and MCR-1 in ST648 and ST156 E.coli isolates from fowl in China [71]. Coexistence of $b l a_{\mathrm{NDM}-1}$ and $b l a_{\mathrm{OXA}-48}$ carrying plasmids was reported in an isolate of K. pneumoniae from China [72]. Similarly, coexistence of $b l a_{\mathrm{NDM}-1}$ and $b l a_{\mathrm{OXA}-23}$ was reported in $A$. baumannii from Nepal [73]. K. pneumoniae of type 11 was reported in Greek to be coproducing two metallo beta-lactamses markers, NDM-1 and VIM-1 together [74]. A report on E. coli isolate obtained from a patient in Thailand and another report from China, showed the presence of colistin resistant mcr-1 gene along with beta lactamases genes such as NDM-1 [75-77]. In E. coli ST471 isolated from Turkey, NDM-1 was found present along with CTX-M-9, TEM, SHV and rmtC [78]. Another coexistence of $b l a_{\mathrm{SHV}-12}$ along with $b l a_{\mathrm{NDM}-13}$ on a selftransferable plasmid of about $54 \mathrm{~kb}$ size isolated from $E$. coli in China was reported [79]. Coproduction of NDM-5 along with mcr-1 in China, NDM-7 along with OXA-48 in Spain and NDM-9 along with MCR-1 in Taiwan was reported recently [80-82]. Also, the presence of both NDM-9 and MCR-1 was reported in Cronobacter sakazakii and E. coli [83].

To date, a number of variants of New Delhi metallo$\beta$-lactamase-1(NDM-1) have been reported. Of these variants, NDM-2 had a substitution of Cysteine to Glycine at position 82 , and amino acid being substituted by alanine at position 28 in place of proline, in A. baumannii [84] (Table 1). However, 16S RNA methylase and extended-spectrum- $\beta$-lactamases were not detected. Moreover, strains carrying $b l a_{\mathrm{NDM}-2}$ lacked detectable plasmids and the $b l a_{\mathrm{NDM}-2}$ was not seen to be transferred by conjugation [84].

Another variant NDM-3 with an amino acid substitution of Aspartate to Asparagine at position 95 was observed in E. coli [85] (Table 1). NDM-3 showed similar enzyme activities against $\beta$-lactams like those of NDM- 1 , although slightly lower $K_{\text {cat }} / K_{m}$ ratios for all the $\beta$-lactams tested except for doripenem was seen, which is caused by the lower $K_{\text {cat }}$ values of NDM-3 being 19.0 to $47.5 \%$ as

Table 1 Genetic variations among the NDM-1 and its variants and its first source of spread

\begin{tabular}{|c|c|c|}
\hline $\begin{array}{l}\text { NDM-1 } \\
\text { variants }\end{array}$ & Amino acid(s) substitution & Source organism(s) \\
\hline NDM-2 & Proline 28 to Alanine & Acinetobacter baumannii \\
\hline NDM-3 & Aspartate 95 to Asparagine & Escherichia coli \\
\hline NDM-4 & Methionine 154 to Leucine & Escherichia coli \\
\hline NDM-5 & $\begin{array}{l}\text { Valine } 88 \text { to Leucine } \\
\text { Methionine } 154 \text { to Leucine }\end{array}$ & Escherichia coli \\
\hline NDM-6 & Alanine 233 to Valine & Escherichia coli \\
\hline NDM-7 & $\begin{array}{l}\text { Aspartate } 130 \text { to Asparagine } \\
\text { Methionine } 154 \text { to Leucine }\end{array}$ & Escherichia coli \\
\hline NDM-8 & $\begin{array}{l}\text { Aspartate } 130 \text { to Glycine } \\
\text { Methionine } 154 \text { to Leucine }\end{array}$ & Escherichia coli \\
\hline NDM-9 & Glutamic Acid 152 to Lysine & Klebsiella pneumoniae \\
\hline NDM-10 & $\begin{array}{l}\text { Arginine } 32 \text { to Serine, } \\
\text { Glycine } 36 \text { toAspartic acid, } \\
\text { Glycine } 69 \text { to serine, } \\
\text { Alanine } 74 \text { to threonine, } \\
\text { Glycine } 200 \text { to Arginine }\end{array}$ & Klebsiella pneumoniae \\
\hline NDM-11 & NA & Escherichia coli \\
\hline NDM-12 & $\begin{array}{l}\text { Glycine } 222 \text { to Aspartic acid } \\
\text { and Methionine } 154 \text { to Leucine }\end{array}$ & Escherichia coli \\
\hline NDM-13 & $\begin{array}{l}\text { Aspartic acid } 95 \text { to Asparagine } \\
\text { and Methionine } 154 \text { to Leucine }\end{array}$ & Escherichia coli \\
\hline NDM-14 & Aspartic acid 130 to Glycine & Acinetobacter Iwoffii \\
\hline NDM-15 & $\begin{array}{l}\text { Alanine } 233 \text { to valine } \\
\text { Methionine } 154 \text { to Leucine }\end{array}$ & Escherichia coli \\
\hline NDM-16 & Arginine 264 to Histidine & Klebsiella pneumoniae \\
\hline NDM-17 & $\begin{array}{l}\text { Valine } 88 \text { to Leucine, Methionine } \\
154 \text { to Leucine and Glutamic acid } \\
170 \text { to Lysine }\end{array}$ & Escherichia coli \\
\hline
\end{tabular}


compared to NDM-1 [86]. In fact, the decreased $\mathrm{K}_{\text {cat }}$ values and the decrease in hydrolysis rate of all tested $\beta$-lactams except for doripenem is due to subsitution of Asn from Asp at position 95. Residue 95 is found to be in $\alpha 1$, located on the surface of the protein [86]. The crystal structure study of NDM-1 revealed that the NDM-1 active site is located at the bottom of a shallow groove being enclosed by two important loops named L3 and L10. However, $\alpha 1$ 95th residue was not located in these loops and indirectly may affect the interaction of the substrate with the active site [86]. Among $9 \mathrm{NDM}$ variants, substitutions of amino acids were identified at 7 different positions $(28,88,95$, $130,152,154$, and 233), but which position(s) plays a critical role in the enzymatic activities, remained unclear. For $b l a_{\mathrm{NDM}-3}$ the genetic context $\operatorname{tnp} A-b l a_{\mathrm{NDM}-3}-b l e_{\mathrm{MBL}^{-}}$ trpF-dsbC-tnpA-sulI-qacEdeltaI-aadA2-dfrA1, was present on approximately $250-\mathrm{kb}$ plasmid. The $b l a_{\mathrm{NDM}-3}$ and $b l a_{\mathrm{NDM}-1}$ gene expression in E. coli $\mathrm{DH} 5 \alpha$ conferred reduced susceptibility and resistance to all cephalosporins, moxalactam, and carbapenems. E. coli expressing NDM-3 showed 2fold higher MIC of cefpirome than the one expressing NDM-1 in contrast to those of 2-fold lower MIC of cefepime, cefoselis, cefotaxime, cefoxitin, imipenem, meropenem, and penicillin $G$ for NDM-3 than NDM-1. Recombinant NDM-3 and NDM-1 hydrolyzed all tested $\beta$ lactams except for aztreonam [86].

NDM-4 variant showed substitution of amino acid from 154th Methionine to Leucine in E. coli [87] (Table 1). NDM-4-producing E. coli isolate from a North Indian hospital sewage was recently reported by Khan and Parvez [15]. Gene expression of bla $a_{\mathrm{NDM}-1}$ and bla $a_{\mathrm{NDM}-4}$ in E. coli TOP10 conferred lower susceptibility or resistance to all $\beta$-lactams except aztreonam. However, the MICs of imipenem and ertapenemwere found to be higher for $E$. coli expressing NDM-4 than the one expressing NDM-1, suggesting the role of Leu154 residue in the high carbapenemase activity [87]. NDM-4 $\beta$-lactamase hydrolyzed all tested $\beta$-lactams except for aztreonam, just similar to other MBLs. Kinetic data showed higher level of hydrolysis of imipenem by NDM-4 than by NDM-1. Similarly, catalytic activity of NDM-4 for meropenem was slightly higher than that of NDM-1. NDM-4 showed higher catalytic efficiencies for cefalotin, ceftazidime, and cefotaxime, as cefepime was less hydrolyzed by NDM-4. Higher $K_{\text {cat }}$ values for NDM-4 than NDM-1 for cefalotin and cefotaxime was also observed. $K_{m}$ values of 72 and $181 \mu \mathrm{M}$ for NDM-4 and NDM-1 was observed, respectively. NDM-4 showed lower affinity for ceftazidime than NDM-1 [87]. $b l a_{\mathrm{NDM}-4}$ was found on IncF type plasmid in one of the earlier studies [88]. A remnant of insertion sequence ISAba125 on upstream of the $b l a_{\mathrm{NDM}-4}$ was found previously by PCR mapping during study of genetic structures surrounding the $b l a_{\mathrm{NDM}-4}$ gene [89]. The $b l e_{\mathrm{MBL}}$, a bleomycin resistant gene, was identified downstream of the $b l a_{\text {NDM-4 }}$, similar genetic environment has been observed for most of the analyzed NDM-1 positive enterobacterial isolates [88]. PCR-based replicon typing showed that this $b l a_{\mathrm{NDM}-4}$ positive plasmid belongs to the IncFIA incompatibility group. In keeping with this, $b_{\text {NDM-5 }}$ was also found associated with IncFIA $[28,87]$.

The substitution of Valine by Leucine at position 88 and Methionine by Leucine at position 154 was found in NDM-5, which was first detected in E.coli [28] (Table 1). NDM-5 shows greater hydrolytic activity than NDM-1 toward carbapenems, cefotaxime, cephalotin and ceftazidime [85]. NDM- 5 carrying plasmid of size $>100 \mathrm{~kb}$ reduced susceptibilities of $E$. coli transformants to carbapenems and cephalosporins [28]. Other detected resistance determinants in NDM-5 producing E. coli included $d f r A 17$ and aadA5 genes, which were found to be located within a class I integron structure, and the $16 \mathrm{~S}$ rRNA methylase gene, $r m t B$, which was thought to account for aminoglycoside high-level resistance. The effect of NDM-5 on susceptibility of $E$. coli to carbapenems and expanded-spectrum cephalosporins appeared to be greater than that of NDM-1. Sequence analysis of $5^{\prime}$-flanking region of $b l a_{\mathrm{NDM}-5}$ allele revealed presence of partial ISAba125, likely to be derived from A. baumannii, which generated a hybrid $(-35 /-10)$ promoter as described earlier by Poirel et al. in an NDM-1-producing E. coli isolate [90]. NDM-6 showed substitution of Alanine to Valine at 233 position, again first time detected in $E$. coli [12] (Table 1).

Substitutions of Aspartate to Asparagine at position 130 and Methionine to Leucine at position 154were found in NDM-7, identified in E. coli ST599 [91] (Table 1). TOP10 cells carrying plasmid harbouring bla $a_{\mathrm{NDM}-7}$ in E.coli conferred higher resistance to carbapenems than a plasmid carrying bla $a_{\mathrm{NDM}-1}$ [91]. A recent report demonstrated the role of Leu154 in enhancing carbapenem MICs in NDM-7 producing $E$. coli strain [91]. The bla $a_{\mathrm{NDM}-7}$ gene was found to be located on a self-transferable IncX3 plasmid of $60 \mathrm{~kb}$.

NDM-8 variant having substitutions at positions 130th (Aspartic acid to Glycine) and 154th (Methionine to Leucine) resulted in enzymatic activities against $\beta$-lactams similar to those shown by NDM-1 [92]. NDM-9 differing by a single amino acid substitution (E152K) from NDM-1 was recently identified in $K$. pneumoniae ST107 strain from China [93].

NDM-10 was first identified in K. pneumoniae isolated from Maharashtra, India and was found to have multiple substitutions at Arginine 32 to Serine, Glycine 36 to Aspartic acid, Glycine 69 to Serine, Alanine 74 to Threonine and Glycine 200 to Arginine [94].

NDM-11 was reported in E. coli KnPEc14 strain (Gene Bank KP265939.1).

NDM-12 has two amino acid substitutions at 154th (Methionine to Leucine) and 222th (Glycine to Aspartic acid). It was first identified on plasmid size $160 \mathrm{~kb}$ in $E$. coli 
[95] (Table 1). NDM-12 enzymatic activities were similar to those of NDM-1 against $\beta$-lactams, although $\mathrm{k}_{\mathrm{cat}} / \mathrm{K}_{\mathrm{m}}$ ratios for all $\beta$-lactams were tested except doripenem.

NDM-13, a novel New Delhi Metallo- $\beta$-lactamase was identified in Nepal from the urine sample of patient showing a carbapenem-resistant E. coli infection [96]. It showed substitutions of Asparagine in place of Aspartic acid at position 95 and Leucine in place of Methionine at position 154 (Table 1 ) and similar enzymatic activity against $\beta$-lactams, but higher $\mathrm{K}_{\mathrm{cat}} / \mathrm{K}_{\mathrm{m}}$ ratios for cefotaxime compared with NDM-1. The bla $a_{\mathrm{NDM}-13}$ gene was located into the chromosome within the genetic environment of tnpA-IS30bla $a_{\mathrm{NDM}-13}-b l e_{\mathrm{MBL}}-t r p F-d s b C$-cutA-groES-groL. Recently, complete sequence of pNDM13-DC33 plasmid harbouring $b l a_{\mathrm{NDM}-13}$ isolated from E. coli isolate ST5138 in China, was reported, consisting of a backbone of $33 \mathrm{~kb}$ size and encoding an antimicrobial resistance region of $21 \mathrm{~kb}$; tra, trb and pil transfer functions; repB plasmid replication gene and stability partitioning. pNDM13-DC33 plasmid harbouring $b l a_{\mathrm{NDM}-13}$ gene showed high similarity with pNDM-HN380 IncX3 plasmid harbouring bla $a_{\mathrm{NDM}-1}$ gene [79].
NDM-14 was first identified in clinical isolate of Acinetobacter lwoffii with substitution of Aspartic acidat 130th position to Glycine [97] (Table 1). NDM-14 showed higher enzymatic activities than NDM-1 towards carbapenem. NDM-14 have higher affinity for meropenem and imipenem than NDM-1, as indicated by the kinetic data [97].

NDM-15 was reported in an E. coli strain (Gene Bank KP735848.1). It showed substitution of Alanine to valine at 233th position and Methionine to Leucine at 154th position.

NDM-16 variant showed substitution at 264th position of Arginine to Histidine [98].

NDM-17 was reported in E.coli strain from a chicken in China. It showed amino acid subsitution of valine 88 to leucine, methionine 154 to leucine and glutamic acid 170 to lysine [99]. Schematic representation of mutations on various nucleotides leading to formation of new NDM variant is shown in Fig. 2. Phylogenetic analysis among the protein sequence of NDM variants are represented as cladogram in Fig. 3.

Carbapenem hydrolysing activity was gradually reduced from NDM-7 to NDM-5, NDM-6 and NDM-1. All

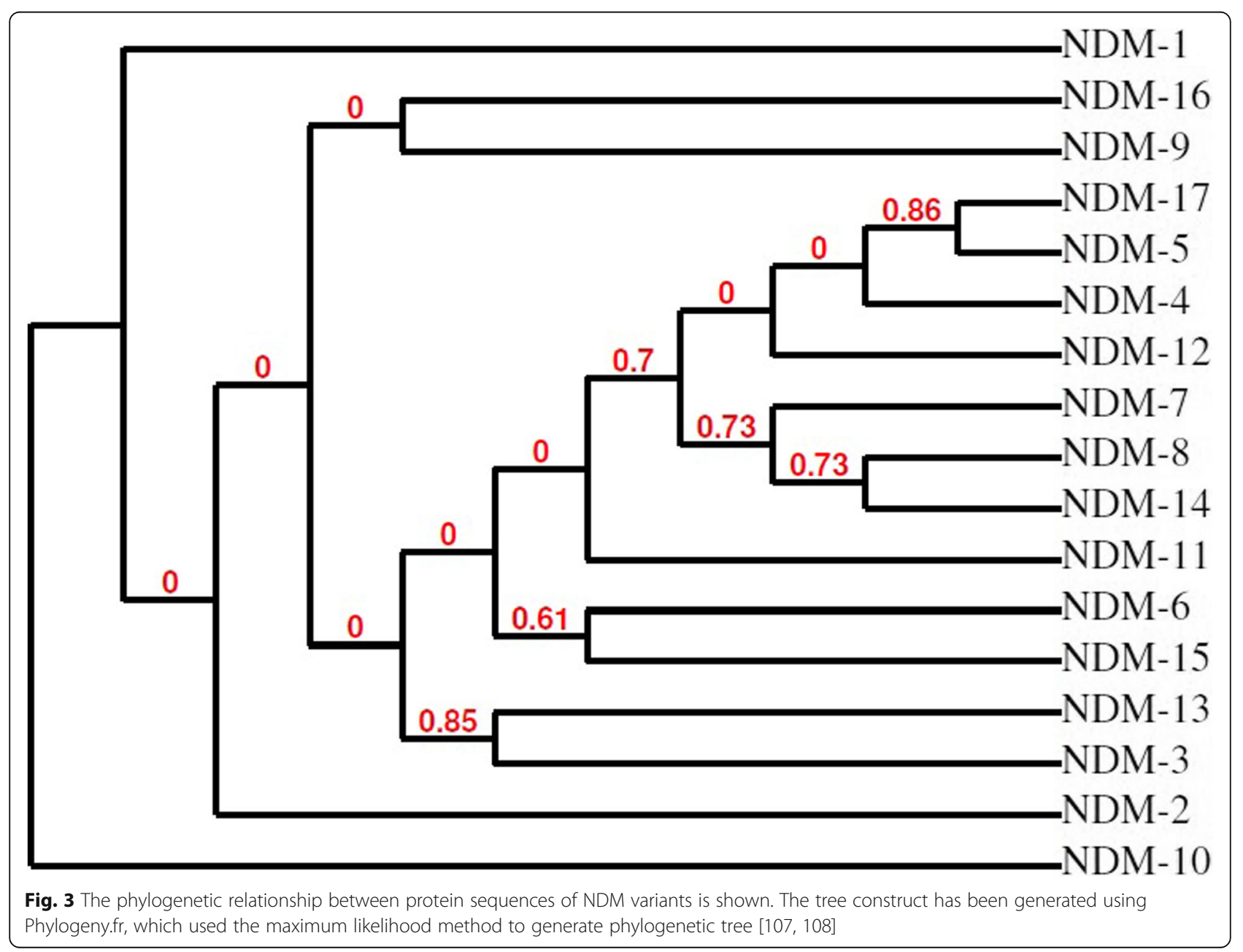


isolates positive for variants of bla $a_{\mathrm{NDM}-1}$ showed resistance to aminoglycosides with MIC greater than $256 \mathrm{mg} / \mathrm{L}$ and MIC range of $2-512 \mathrm{mg} / \mathrm{L}$ for different lactams, lactams/lactamase inhibitor combinations [100]. Moreover, these variants showed susceptibility to tigecycline and colistin except for KNKp6a isolate, which showed MIC of $1.5 \mathrm{mg} / \mathrm{L}$ to tigecycline [100].

NDM variants were found associated with all other groups of antibiotic resistance enzymes encoding genes i.e. ESBL, carbapenemase, AmpC and rRNAmethylase. In $b l a_{\mathrm{NDM}}$ and its variants, due to genetic co-existence of other antibiotic resistant markers, there is limited options left to treat infections [101].

Recently, an NDM-1 producing Cedecea lapagei isolated from a neonate admitted to the paediatric ICU of a north India hospital was reported from our lab [102]. Also, a recent study demonstrated that 11 out of 55 patients with carbapenem-resistant Enterobacteriaceae nosocomial infections in China showed NDM variants as carbapenemase genes [103]. Recently, metabolite aspergillomarasmine A (AMA) which is found in fungi and its natural LLL isomer were identified to be effective inactivators of NDM-1 enzyme both in vivo and in vitro [104]. Also, the combination of levofloxacin and tigecyclinewas recently reported to successfully treat nosocomial pneumonia caused by NDM-1 producing Raoultella planticola [105].

\section{Conclusion}

The continual evolution of resistant markers due to the selection pressure and their spread among the bacteria through horizontal gene transfer is one of the alarming threats to the health worker in the hospital settings in order to control infections. NDM-1 and its variants producing bacteria was one of the challenges, which has became even more urgent since the detection of $\mathrm{mcr}-1$ gene in Chinaand the spread of resistance against colistin has ended all hopes to control infections [77]. Now this is a time to think prudently the ways to check infections from hospital settings and to coordinate globally for surveillance of such resistant markers producing bacteria. Proper infection control guidelines need to be implemented worldwide. Surveillance should also be carried out to identify undetected asymptomatic carriers of carbapenem-resistant bacteria. To discover new drug molecules which could fight with multi-resistant bacteria, Infectious Disease Society of America has launched a "bad bugs need drugs" campaign to promote development of new antibiotics by 2020 [106].

\section{Additional file}

Additional file 1: Table S1. Worldwide distribution of NDM producing bacteria, as per articles available on PubMed database in the time period of Dec 2013 to Feb 2017. (PDF $136 \mathrm{~kb}$ )

\section{Abbreviations}

AMA: Aspergillomarasmine A; BLIs: Beta lactamse inhibitors;

CPOs: Carbapenem producing organisms; CRE: Carbapenem resistant enterobacteriaceae; ESBL: Extended spectrum beta lactamase; MBLs: Metallo beta lactamses; MDRPA: Muti-drug-resistant pseudomonas aeruginosa; MRSA: Methicillin resistant Staphylococcus aureus; NDM: New delhimetallo beta lactamse; PBPs: Penicillin binding proteins

\section{Availability of data and materials}

All data included in this study are publicly available because they have been published already.

\section{Authors' contribution}

AUK conceived idea of compiling review and completed first draft. LM updated the information on genetics and structure of NDM-1 and helped writing, and preparing figs. RZ reviewed and critically revised it as per the current scenario. All authors read and approved the final manuscript.

Competing interests

Author's declare that there is no competing interest.

Consent for publication

All authors agree to submit in BMC Microbiology.

Ethics approval and consent to participate

Not applicable.

\section{Author details}

${ }^{1}$ Medical Microbiology and Molecular Biology Laboratory, Interdisciplinary Biotechnology Unit, Aligarh Muslim University, Aligarh 202002, India.

${ }^{2}$ Department of Public Health, University of Napoli Federico II, Italy, Naples, Italy. ${ }^{3}$ CEINGE Biotecnologie Avanzate, Naples, Italy.

Received: 15 March 2017 Accepted: 14 April 2017

Published online: 27 April 2017

References

1. Woodford N, Ellington MJ. The emergence of antibiotic resistance by mutation. Clin Microbiol Infect. 2007;13:5-18.

2. Gould IM, Bal AM. New antibiotic agents in the pipeline and how they can help overcome microbial resistance. Virulence. 2013;4:185-91.

3. Winkler ML, Bonomo RA. SHV-129: A gateway to global suppressors in the SHV beta-Lactamase Family? Mol Biol Evol. 2016;33:429-41.

4. Queenan AM, Bush K. Carbapenemases: the versatile beta-lactamases. Clin Microbiol Rev. 2007;20:440-58.

5. Viau R, Frank KM, Jacobs MR, Wilson B, Kaye K, Donskey CJ, Perez F, Endimiani A, Bonomo RA. Intestinal carriage of carbapenemase-producing organisms: current status of surveillance methods. Clin Microbiol Rev. 2016;29:1-27.

6. Bush K, Pannell M, Lock JL, Queenan AM, Jorgensen JH, Lee RM, Lewis JS, Jarrett D. Detection systems for carbapenemase gene identification should include the SME serine carbapenemase. Int J Antimicrob Agents. 2013;41:1-4.

7. Chia JH, Siu LK, Su LH, Lin HS, Kuo AJ, Lee MH, Wu TL. Emergence of carbapenem-resistant Escherichia coli in Taiwan: resistance due to combined CMY-2 production and porin deficiency. J Chemother. 2009;21:621-6.

8. Mojica MF, Bonomo RA. Fast W.B1-Metallo-beta-Lactamases: Where Do We Stand? Curr Drug Targets. 2016;17:1029-50.

9. Aitha M, Moller AJ, Sahu ID, Horitani M, Tierney DL, Crowder MW. Investigating the position of the hairpin loop in New Delhi metallo-betalactamase, NDM-1, during catalysis and inhibitor binding. J Inorg Biochem. 2016;156:35-9.

10. Bush K. A resurgence of beta-lactamase inhibitor combinations effective against multidrug-resistant Gram-negative pathogens. Int J Antimicrob Agents. 2015;46:483-93.

11. Padhi S. New Delhi metallo-beta-lactamase: a weapon for the newly emerging drug-resistant bacteria. Indian J Med Sci. 2011;65:317-20.

12. Kaase M, Nordmann P, Wichelhaus TA, Gatermann SG, Bonnin RA, Poirel L. NDM-2 carbapenemase in Acinetobacter baumannii from Egypt. J Antimicrob Chemother. 2011;66:1260-2.

13. Khan AU, Nordman P. Spread of carbapenemase NDM-1 producers: the situation in India and what may be proposed. Scand J Infect Dis. 2012;44:531-5. 
14. Williamson DA, Sidjabat HE, Freeman JT, Roberts SA, Silvey A, Woodhouse R, Mowat E, Dyet K, Paterson DL, Blackmore T, Burns A, Heffernan $\mathrm{H}$. Identification and molecular characterisation of New Delhi metallo-betalactamase-1 (NDM-1)- and NDM-6-producing Enterobacteriaceae from New Zealand hospitals. Int J Antimicrob Agents. 2012;39:529-33.

15. Khan AU, Parvez S. Detection of bla(NDM-4) in Escherichia coli from hospital sewage. J Med Microbiol. 2014;63:1404-6.

16. Köhler T, Michea-Hamzehpour M, Epp SF, Pechere JC. Carbapenem activities against Pseudomonas aeruginosa: respective contributions of OprD and efflux systems. Antimicrob Agents Chemother. 1999;43:424-7.

17. Bush K, Jacoby GA, Medeiros AA. A functional classification scheme for beta-lactamases and its correlation with molecular structure. Antimicrob Agents Chemother. 1995;39:1211-33.

18. Nordmann P, Cuzon G, Naas T. The real threat of Klebsiella pneumoniae carbapenemase-producing bacteria. Lancet Infect Dis. 2009;9:228-36.

19. Jovcic B, Lepsanovic Z, Suljagic V, Rackov G, Begovic J, Topisirovic L, Kojic M. Emergence of NDM-1 metallo-beta-lactamase in Pseudomonas aeruginosa clinical isolates from Serbia. Antimicrob Agents Chemother. 2011;55:3929-31.

20. Khajuria A, Praharaj AK, Kumar M, Grover N. Emergence of NDM-1 in the clinical isolates of Pseudomonas aeruginosa in India. J Clin Diagn Res. 2013:7:1328-31.

21. Choudhury D, Paul D, Ghosh AS, Das Talukdar A, Dutta Choudhury M, Maurya AP, Dhar Chanda D, Chakravarty A, Bhattacharjee A. Effect of singledose carbapenem exposure on transcriptional expression of blaNDM-1 and mexA in Pseudomonas aeruginosa. J Glob Antimicrob Resist. 2016;7:72-7.

22. Ruppé É, Woerther PL, Barbier F. Mechanisms of antimicrobial resistance in Gram-negative bacilli. Ann Intensive Care. 2015;5:61.

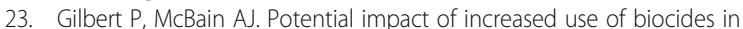
consumer products on prevalence of antibiotic resistance. Clin Microbiol Rev. 2003:16:189-208.

24. Brovedan M, Marchiaro PM, Morán-Barrio J, Revale S, Cameranesi M, Brambilla L, Viale AM, Limansky AS. Draft genome sequence of Acinetobacter bereziniae HPC229, a carbapenem-resistant clinical strain from Argentina harboring blaNDM-1. Genome Announc. 2016;4:pii:e00117-16.

25. Pfeifer Y, Cullik A, Witte W. Resistance to cephalosporins and carbapenems in Gram-negative bacterial pathogens. Int J Med Microbiol. 2010;300:371-9.

26. Martinez-Martinez L, Pascual A, Hernández-Allés S, Alvarez-Díaz D, Suárez Al, Tran J, Benedí VJ, Jacoby GA. Roles of beta-lactamases and porins in activities of carbapenems and cephalosporins against Klebsiella pneumoniae. Antimicrob Agents Chemother. 1999:43:1669-73.

27. Wright GD. Bacterial resistance to antibiotics: enzymatic degradation and modification. Adv Drug Deliv Rev. 2005;57:1451-70.

28. Hornsey M, Phee L, Wareham DW. A novel variant, NDM-5, of the New Delhi metallo-beta-lactamase in a multidrug-resistant Escherichia coli ST648 isolate recovered from a patient in the United Kingdom. Antimicrob Agents Chemother. 2011;55:5952-4.

29. Yang $H$, Aitha M, Hetrick AM, Richmond TK, Tierney DL, Crowder MW. Mechanistic and spectroscopic studies of metallo-beta-lactamase NDM-1. Biochemistry. 2012;51:3839-47.

30. Miriagou V, Cornaglia G, Edelstein M, Galani I, Giske CG, Gniadkowski M, et al. Acquired carbapenemases in Gram-negative bacterial pathogens: detection and surveillance issues. Clin Microbiol Infect. 2010;16:112-22.

31. Rolain JM, Parola P, Cornaglia G. New Delhi metallo-beta-lactamase (NDM1): towards a new pandemia? Clin Microbiol Infect. 2010;16:1699-701.

32. $\mathrm{Hu} H, \mathrm{Hu} Y$, Pan $Y$, Liang $H$, Wang $H$, Wang $X$, et al. Novel plasmid and its variant harboring both a bla(NDM-1) gene and type IV secretion system in clinical isolates of Acinetobacter Iwoffii. Antimicrob Agents Chemother. 2012;56:1698-702.

33. Bogaerts P, Verroken A, Jans B, Denis O, Glupczynski Y. Global spread of New Delhi metallo-beta-lactamase 1. Lancet Infect Dis. 2010;10:831-2.

34. Kumarasamy KK, Toleman MA, Walsh TR, Bagaria J, Butt F, Balakrishnan R, et al. Emergence of a new antibiotic resistance mechanism in India, Pakistan, and the UK: a molecular, biological, and epidemiological study. Lancet Infect Dis. 2010;10:597-602.

35. Bonnin RA, Poirel L, Naas T, Pirs M, Seme K, Schrenzel J, Nordmann P. Dissemination of New Delhi metallo- $\beta$-lactamase-1-producing Acinetobacter baumannii in Europe. Clin Microbiol Infect. 2012;18:E362-5.

36. Sahl JW, Del Franco M, Pournaras S, Colman RE, Karah N, Dijkshoorn L, Zarrilli R. Phylogenetic andgenomic diversity in isolates from the globally distributed Acinetobacter baumannii ST25 lineage. Sci Rep. 2015;5:15188.

37. Szmolka A, Nagy B. Multidrug resistant commensal Escherichia coli in animals and its impact for public health. Front Microbiol. 2013;4:258.
38. Wang Y, Wu C, Zhang Q, Qi J, Liu H, Wang Y, et al. Identification of New Delhi metallo-beta-lactamase 1 in Acinetobacter /woffii of food animal origin. PLoS One. 2012;7:e37152.

39. Khan AU, Nordmann P. NDM-1-producing Enterobacter cloacae and Klebsiella pneumoniae from diabetic foot ulcers in India. J Med Microbiol. 2012;61:454-6.

40. Yong D, Toleman MA, Giske CG, Cho HS, Sundman K, Lee K, Walsh TR. Characterization of a new metallo-beta-lactamase gene, bla(NDM-1), and a novel erythromycin esterase gene carried on a unique genetic structure in Klebsiella pneumoniae sequence type 14 from India. Antimicrob Agents Chemother. 2009:53:5046-54.

41. Bush K, Jacoby GA. Updated functional classification of beta-lactamases. Antimicrob Agents Chemother. 2010;54:969-76.

42. Janvier F, Jeannot K, Tessé S, Robert-Nicoud M, Delacour H, Rapp C, Mérens A. Molecular characterization of blaNDM-1 in a sequence type 235 Pseudomonas aeruginosa isolate from France. Antimicrob Agents Chemother. 2013;57:3408-11.

43. Gamal D, Fernández-Martínez M, Salem D, El-Defrawy I, Montes LÁ, Ocampo-Sosa AA, Martínez-Martínez L. Carbapenem-resistant Klebsiella pneumoniae isolates from Egypt containing blaNDM-1 on IncR plasmids and its association with rmtF. Int J Infect Dis. 2016;43:17-20.

44. Yao X, Doi Y, Zeng L, Lv L, Liu JH. Carbapenem-resistant and colistinresistant Escherichia coli co-producing NDM-9 and MCR-1. Lancet Infect Dis. 2016;16:288-9.

45. Rahman M, Prasad KN, Pathak A, Pati BK, Singh A, Ovejero CM, et al. RmtC and RmtF 165 rRNA Methyltransferase in NDM-1-Producing Pseudomonas aeruginosa. Emerg Infect Dis. 2015;21:2059-62.

46. Kocsis E, Gužvinec M, Butić I, Krešić S, Crnek SŠ, Tambić A, et al. blaNDM-1 carriage on IncR plasmid in Enterobacteriaceae strains. Microb Drug Resist. 2016;22:123-8.

47. Datta S, Mitra S, Chattopadhyay P, Som T, Mukherjee S, Basu S. Spread and exchange of bla NDM-1 in hospitalized neonates: role of mobilizable genetic elements. Eur J Clin Microbiol Infect Dis. 2017;36:255-65.

48. Bontron S, Nordmann P, Poirel L. Transposition of Tn125 encoding the NDM-1 carbapenemase in Acinetobacter baumannii. Antimicrob Agents Chemother. 2016;60:7245-51

49. Dortet L, Girlich D, Virlouvet AL, Poirel L, Nordmann P, lorga BI, Naas T. Characterization of BRPMBL, the bleomycin resistance protein associated with the Carbapenemase NDM. Antimicrob Agents Chemother. 2017;61:pii:e02413-16. Print 2017.

50. Cornaglia G, Rossolini GM. Forthcoming therapeutic perspectives for infections due to multidrug-resistant Gram-positive pathogens. Clin Microbiol Infect. 2009;15:218-23.

51. Silhavy TJ, Kahne D, Walker S. The bacterial cell envelope. Cold Spring Harb Perspect Biol. 2010;2:a000414.

52. Baiden F, Owusu-Agyei S, Webster J, Chandramohan D. The need for new antibiotics. Lancet. 2010;375:637-8.

53. Heddini A, Cars O, Qiang S, Tomson G. Antibiotic resistance in China-a major future challenge. Lancet. 2009;373:30.

54. Thabit AK, Crandon JL, Nicolau DP. Antimicrobial resistance: impact on clinical and economic outcomes and the need for new antimicrobials. Expert Opin Pharmacother. 2015;16:159-77.

55. Marquez-Ortiz RA, Haggerty L, Sim EM, Duarte C, Castro-Cardozo BE, Beltran M, et al. First complete Providencia rettgeri genome sequence, the NDM-1producing clinical strain RB151. Genome Announc. 2017;5:pii:e01472-16.

56. Shen P, Yi M, Fu Y, Ruan Z, Du X, Yu Y, Xie X. Detection of an Escherichia coli sequence type 167 strain with two tandem copies of blaNDM-1 in the chromosome. J Clin Microbiol. 2016;55:199-205.

57. Livermore DM. Has the era of untreatable infections arrived? J Antimicrob Chemother. 2009;64(Suppl 1):i29-36.

58. Chen Z, Qlu S, Wang Y, Wang Y, Liu S, Wang Z, et al. Coexistence of blaNDM-1 with the prevalent blaOXA23 and blalMP in pan-drug resistant Acinetobacter baumannii isolates in China. Clin Infect Dis. 2011;52:692-3.

59. Shon AS, Bajwa RP, Russo TA. Hypervirulent (hypermucoviscous) Klebsiella pneumoniae: a new and dangerous breed. Virulence. 2013:4:107-18.

60. Daikos GL, Markogiannakis A, Souli M, Tzouvelekis LS. Bloodstream infections caused by carbapenemase-producing Klebsiella pneumoniae: a clinical perspective. Expert Rev Anti-Infect Ther. 2012;10:1393-404.

61. Frere JM, Galleni M, Bush K, Dideberg O. Is it necessary to change the classification of \{beta\}-lactamases? J Antimicrob Chemother. 2005;55:1051-3.

62. Poirel L, Dortet L, Bernabeu S, Nordmann P. Genetic features of blaNDM-1 positive Enterobacteriaceae. Antimicrob Agents Chemother. 2011;55:5403-7. 
63. Wailan AM, Sidjabat HE, Yam WK, Alikhan NF, Petty NK, Sartor AL, et al Mechanisms involved in acquisition of blaNDM genes by IncA/C2 and IncFIIY plasmids. Antimicrob Agents Chemother. 2016;60:4082-8.

64. Mishra S, Upadhyay S, Sen MR, Maurya AP, Choudhury D, Bhattacharjee A. Genetic acquisition of NDM gene offers sustainability among clinical isolates of Pseudomonas aeruginosa in clinical settings. PLoS One. 2015;10:e0116611.

65. Campos JC, da Silva MJ, dos Santos PR, Barros EM, Pereira Mde O, Seco BM, et al. Characterization of Tn3000, a transposon responsible for blaNDM-1 dissemination among Enterobacteriaceae in Brazil, Nepal, Morocco, and India. Antimicrob Agents Chemother. 2015:59:7387-95.

66. Khan AU, Rehman MT. Role of non-active-site residue Trp-93 in the function and stability of New Delhi Metallo-beta-Lactamase 1. Antimicrob Agents Chemother. 2015;60:356-60.

67. Zhang F, Xie L, Wang X, Han L, Guo X, Ni Y, Qu H, Sun J. Further spread of bla NDM-5 in Enterobacteriaceae via IncX3 Plasmids in Shanghai, China. Front Microbiol. 2016;7:424.

68. An J, Guo L, Zhou L, Ma Y, Luo Y, Tao C, Yang J. NDM-producing Enterobacteriaceae in a Chinese Hospital, 2014-2015: Identification of NDMproducing Citrobacter werkmanii and acquisition of blaNDM-1-carrying plasmid in vivo in a clinical Escherichia coli isolate. J Med Microbiol. 2016;65:1253-9.

69. Tran DN, Tran HH, Matsui M, Suzuki M, Suzuki S, Shibayama K, et al. Emergence of New Delhi metallo-beta-lactamase 1 and other carbapenemase-producing Acinetobacter calcoaceticus-baumannii complex among patients in hospitals in Ha Noi, Viet Nam. Eur J Clin Microbiol Infect Dis. 2017;36:219-25.

70. Both A, Huang J, Kaase M, Hezel J, Wertheimer D, Fenner I, et al. First report of Escherichia coli co-producing NDM-1 and OXA-232. Diagn Microbiol Infect Dis. 2016;86:437-8.

71. Yang RS, Feng $Y, L v X Y$, Duan JH, Chen J, Fang LX, et al. Emergence of NDM-5 and MCR-1-producing Escherichia coli clone ST648 and ST156 from a single Muscovy Duck (Cairina moschata). Antimicrob Agents Chemother. 2016;60:6899-902.

72. Xie L, Dou Y, Zhou K, Chen Y, Han L, Guo X, Sun J. Coexistence of blaOXA48 and truncated blaNDM-1 on different plasmids in a Klebsiella pneumoniae isolate in China. Front Microbiol. 2017:8:133.

73. Joshi PR, Acharya M, Kakshapati T, Leungtongkam U, Thummeepak R, Sitthisak S. Co-existence of blaOXA-23 and blaNDM-1 genes of Acinetobacter baumannii isolated from Nepal: antimicrobial resistance and clinical significance. Antimicrob Resist Infect Control. 2017;6:21.

74. Papagiannitsis CC, Malli E, Florou Z, Sarrou S, Hrabak J, Mantzarlis K, Zakynthinos E, Petinaki E. Emergence of sequence type 11 Klebsiella pneumoniae coproducing NDM-1 and VIM-1 metallo- $\beta$-lactamases in a Greek hospital. Diagn Microbiol Infect Dis. 2016;87:295-7.

75. Paveenkittiporn W, Kerdsin A, Chokngam S, Bunthi C, Sangkitporn S, Gregory $\mathrm{CJ}$. Emergence of plasmid-mediated colistin resistance and New Delhi metallo$\beta$-lactamase genes in extensively drug-resistant Escherichia coli isolated from a patient in Thailand. Diagn Microbiol Infect Dis. 2017:87:157-9.

76. Zhong LL, Zhang YF, Doi Y, Huang X, Zhang XF, Zeng KJ, et al. Coproduction of MCR-1 and NDM-1 by colistin-resistant Escherichia coli isolated from a healthy individual. Antimicrob Agents Chemother. 2017;61: pii:e01962-16.

77. Zheng B, Dong H, Xu H, Lv J, Zhang J, Jiang X, Du Y, Xiao Y, Li L. Coexistence of MCR-1 and NDM-1 in clinical isolates. Clin Infect Dis. 2016;63:1393-5.

78. Kapmaz M, Erdem F, Abulaila A, Yeniaras E, Oncul O, Aktas Z. First detection of NDM-1 with CTX-M-9, TEM, SHV and rmtC in Escherichia coli ST471 carrying Incl2, A/C and $Y$ plasmids from clinical isolates in Turkey. J Glob Antimicrob Resist. 2016;7:152-3

79. Lv J, Qi X, Zhang D, Zheng Z, Chen Y, Guo Y, et al. First Report of Complete Sequence of a blaNDM-13-harboring plasmid from an Escherichia coli ST5138 clinical isolate. Front Cell Infect Microbiol. 2016;6:130.

80. Quan J, Li X, Chen Y, Jiang Y, Zhou Z, Zhang H, Sun L, Ruan Z, Feng Y, Akova M, Yu Y. Prevalence of mcr-1 in Escherichia coli and Klebsiella pneumoniae recovered from bloodstream infections in China: a multicentre longitudinal study. Lancet Infect Dis. 2017;17:400-10.

81. Lázaro-Perona F, Sarria-Visa A, Ruiz-Carrascoso G, Mingorance J, GarcíaRodríguez J, Gómez-Gil R. Klebsiella pneumoniae co-producing NDM-7 and OXA-48 carbapenemases isolated from a patient with prolonged hospitalisation. Int J Antimicrob Agents. 2016;49:112-3.

82. Lai CC, Chuang YC, Chen CC, Tang HJ. Coexistence of MCR-1 and NDM-9 in a clinical carbapenem-resistant Escherichia coli isolate. Int J Antimicrob Agents. 2017:49:517-8.

83. Liu BT, Song FJ, Zou M, Hao ZH, Shan H. Emergence of colistin resistance gene mcr-1 in Cronobacter sakazakii producing NDM-9 and in Escherichia coli from the same animal. Antimicrob Agents Chemother. 2017;61:pii: e02347-16.

84. Du H, Chen L, Chavda KD, Pandey R, Zhang H, Xie X, Tang MW, Kreiswirth BN. Genomic characterization of Enterobacter cloacae isolates from China that coproduce KPC-3 and NDM-1 carbapenemases. Antimicrob Agents Chemother 2016;60:2519-23.

85. Rogers BA, Sidjabat HE, Silvey A, Anderson TL, Perera S, Li J, Paterson DL. Treatment options for New Delhi metallo-beta-lactamase-harboring enterobacteriaceae. Microb Drug Resist. 2013;19:100-3.

86. Tada T, Miyoshi-Akiyama T, Shimada K, Kirikae T. Biochemical analysis of metallo-beta-lactamase NDM-3 from a multidrug-resistant Escherichia coli strain isolated in Japan. Antimicrob Agents Chemother. 2014;58:3538-40.

87. Nordmann P, Boulanger AE, Poirel L. NDM-4 metallo-beta-lactamase with increased carbapenemase activity from Escherichia coli. Antimicrob Agents Chemother. 2012;56:2184-6.

88. Carattoli A, Bertini A, Villa L, Falbo V, Hopkins KL, Threlfall EJ. Identification of plasmids by PCR-based replicon typing. J Microbiol Methods. 2005;63:219-28.

89. Poirel L, Bonnin RA, Nordmann P. Analysis of the resistome of a multidrugresistant NDM-1-producing Escherichia coli strain by high-throughput genome sequencing. Antimicrob Agents Chemother. 2011;55:4224-9.

90. Dortet L, Nordmann P, Poirel L. Association of the emerging carbapenemase NDM-1 with a bleomycin resistance protein in Enterobacteriaceae and Acinetobacter baumannii. Antimicrob Agents Chemother. 2012;56:1693-7.

91. Gottig S, Hamprecht AG, Christ S, Kempf VA, Wichelhaus TA. Detection of NDM-7 in Germany, a new variant of the New Delhi metallo-beta-lactamase with increased carbapenemase activity. J Antimicrob Chemother. 2013;68:1737-40.

92. Tada T, Miyoshi-Akiyama T, Dahal RK, Sah MK, Ohara H, Kirikae T, Pokhrel BM. NDM-8 metallo-beta-lactamase in a multidrug-resistant Escherichia coli strain isolated in Nepal. Antimicrob Agents Chemother. 2013;57:2394-6.

93. Wang X, Li H, Zhao C, Chen H, Liu J, Wang Z, et al. Novel NDM-9 metallobeta-lactamase identified from a ST107 Klebsiella pneumoniae strain isolated in China. Int J Antimicrob Agents. 2014;44:90-1.

94. Khajuria A, Praharaj AK, Kumar M, Grover N. Presence of a novel variant NDM-10, of the New Delhi metallo-beta-lactamase in a Klebsiella pneumoniae isolate. Indian J Med Microbiol. 2016;34:121-3.

95. Tada T, Shrestha B, Miyoshi-Akiyama T, Shimada K, Ohara H, Kirikae T, Pokhrel BM. NDM-12, a novel New Delhi metallo-beta-lactamase variant from a carbapenem-resistant Escherichia coli clinical isolate in Nepal. Antimicrob Agents Chemother. 2014;58:6302-5.

96. Shrestha B, Tada T, Miyoshi-Akiyama T, Shimada K, Ohara H, Kirikae T, Pokhrel BM. Identification of a novel NDM variant, NDM-13, from a multidrug-resistant Escherichia coli clinical isolate in Nepal. Antimicrob Agents Chemother. 2015:59:5847-50.

97. Zou D, Huang Y, Zhao X, Liu W, Dong D, Li H, et al. A novel New Delhi metallo-beta-lactamase variant, NDM-14, isolated in a Chinese Hospital possesses increased enzymatic activity against carbapenems. Antimicrob Agents Chemother. 2015;59:2450-3.

98. Kazmierczak KM, Rabine S, Hackel M, McLaughlin RE, Biedenbach DJ, Bouchillon SK, Sahm DF, Bradford PA. Multiyear, Multinational Survey of the Incidence and Global Distribution of Metallo-beta-Lactamase-Producing Enterobacteriaceae and Pseudomonas aeruginosa. Antimicrob Agents Chemother. 2016;60:1067-78.

99. Liu Z, Wang Y, Walsh TR, Liu D, Shen Z, Zhang R, et al. Plasmid-mediated novel blaNDM-17 gene encoding a carbapenemase with enhanced activity in a ST48 Escherichia coli strain. Antimicrob Agents Chemother. 2017. [Epub ahead of print].

100. Rahman M, Shukla SK, Prasad KN, Ovejero CM, Pati BK, Tripathi A, et al. Prevalence and molecular characterisation of New Delhi metallo- $\beta$ lactamases NDM-1, NDM-5, NDM-6 and NDM-7 in multidrug resistant Enterobacteriaceae from India. Int J Antimicrob Agents. 2014;44:30-7.

101. Sidjabat HE, Townell N, Nimmo GR, George NM, Robson J, Vohra R, et al. Dominance of IMP-4-producing Enterobacter cloacae among carbapenemase-producing Enterobacteriaceae in Australia. Antimicrob Agents Chemother. 2015;59:4059-66.

102. Ahmad N, Ali SM, Khan AU. First reported New Delhi metallo- $\beta$-lactamase-1producing Cedecea lapagei. Int J Antimicrob Agents. 2017:49:118-9.

103. Wang Q, Zhang Y, Yao X, Xian H, Liu Y, Li H, et al. Risk factors and clinical outcomes for carbapenem-resistant Enterobacteriaceae nosocomial infections. Eur J Clin Microbiol Infect Dis. 2016;35:1679-89.

104. Albu SA, Koteva K, King AM, Al-Karmi S, Wright GD, Capretta A. Total synthesis of aspergillomarasmine $A$ and related compounds: A sulfamidate 
approach enables exploration of structure-activity relationships. Angew Chem Int Ed Engl. 2016;55:13259-62.

105. Pan Z, Liu R, Zhang P, Zhou H, Fu Y, Zhou J. Combination of tigecycline and levofloxacin for successful treatment of nosocomial pneumonia caused by New Delhi Metallo- $\beta$-Lactamase-1-producing Raoultella planticola. Microb Drug Resist. 2016;23:127-31.

106. Boucher HW, Talbot GH, Bradley JS, Edwards JE, Gilbert D, Rice LB, et al. Bad bugs, no drugs: no ESKAPE! An update from the Infectious Diseases Society of America. Clin Infect Dis. 2009;48:1-12.

107. Dereeper A, Guignon V, Blanc G, Audic S, Buffet S, Chevenet F, et al. Phylogeny.fr: robust phylogenetic analysis for the non-specialist. Nucleic Acids Res. 2008;36:W465-9.

108. Dereeper A, Audic S, Claverie JM, Blanc G. BLAST-EXPLORER helps you building datasets for phylogenetic analysis. BMC Evol Biol. 2010;10:8.

Submit your next manuscript to BioMed Central and we will help you at every step:

- We accept pre-submission inquiries

- Our selector tool helps you to find the most relevant journal

- We provide round the clock customer support

- Convenient online submission

- Thorough peer review

- Inclusion in PubMed and all major indexing services

- Maximum visibility for your research

Submit your manuscript at www.biomedcentral.com/submit
Biomed Central 